\title{
Landslide Monitoring in the Atlantic Highlands area, New Jersey
}

Shallow and deep-seated landslides have occurred episodically on the steep coastal bluffs of the Atlantic Highlands area (Boroughs of Atlantic Highlands and Highlands) in New Jersey (fig. 1). The oldest documented deep-seated landslide occurred in April 1782 and significantly changed the morphology of the bluff (Minard, 1974). However, recent landslides have been mostly shallow in nature and have occurred during large storms with exceptionally heavy rainfall (fig. 2; Ashland and others, 2017). These shallow landslides have resulted in considerable damage to residential property and local infrastructure and threatened human safety.

The recent shallow landslides in the area (figs. 1 and 2; locations modified from New Jersey Department of Environmental Protection [NJDEP], 2016) consist primarily of slumps and flows of earth and debris within areas of historical landslides or on slopes modified by human activities (Ashland and others, 2017). Such landslides are typically triggered by increases in shallow soil moisture and pore-water pressure caused by

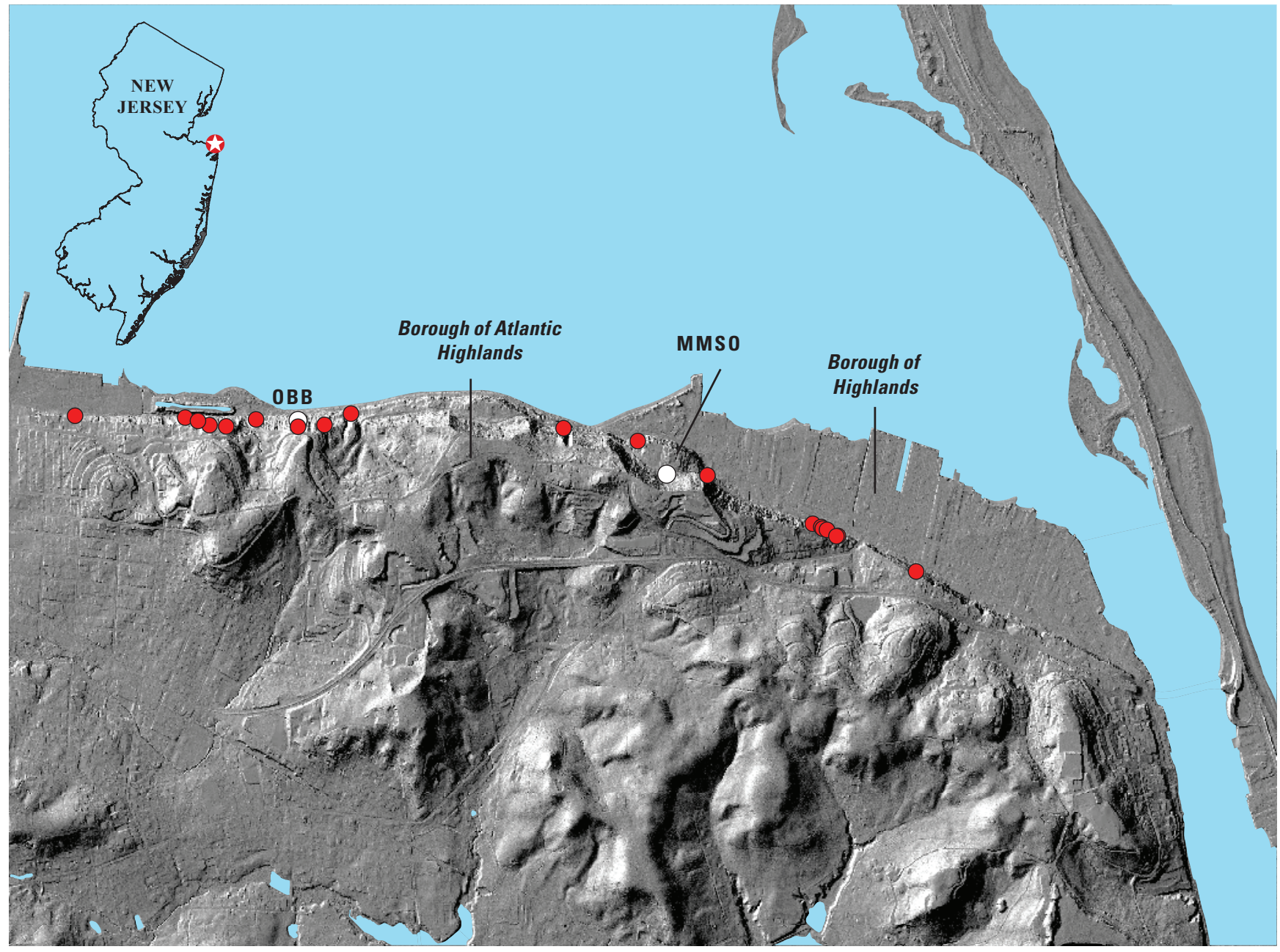

Base from U.S. Geological Survey digital line graph files, 1:24,000, Universal Transverse Mercator projection, Zone 18, NAD 83 Elevation data was derived from the EAARL-B Coastal Topography dataset for Eastern New Jersey, U.S. Geological Survey, St. Petersburg Coastal and Marine Science Center, 2014.

Figure 1. Shaded relief map of the Atlantic Highlands area, New Jersey, showing the location of recent shallow landslides (red circles; NJDEP, 2016), and the Mount Mitchell Scenic Overlook (MMSO) and Ocean Boulevard Bridge (OBB) monitoring sites (white circles). 


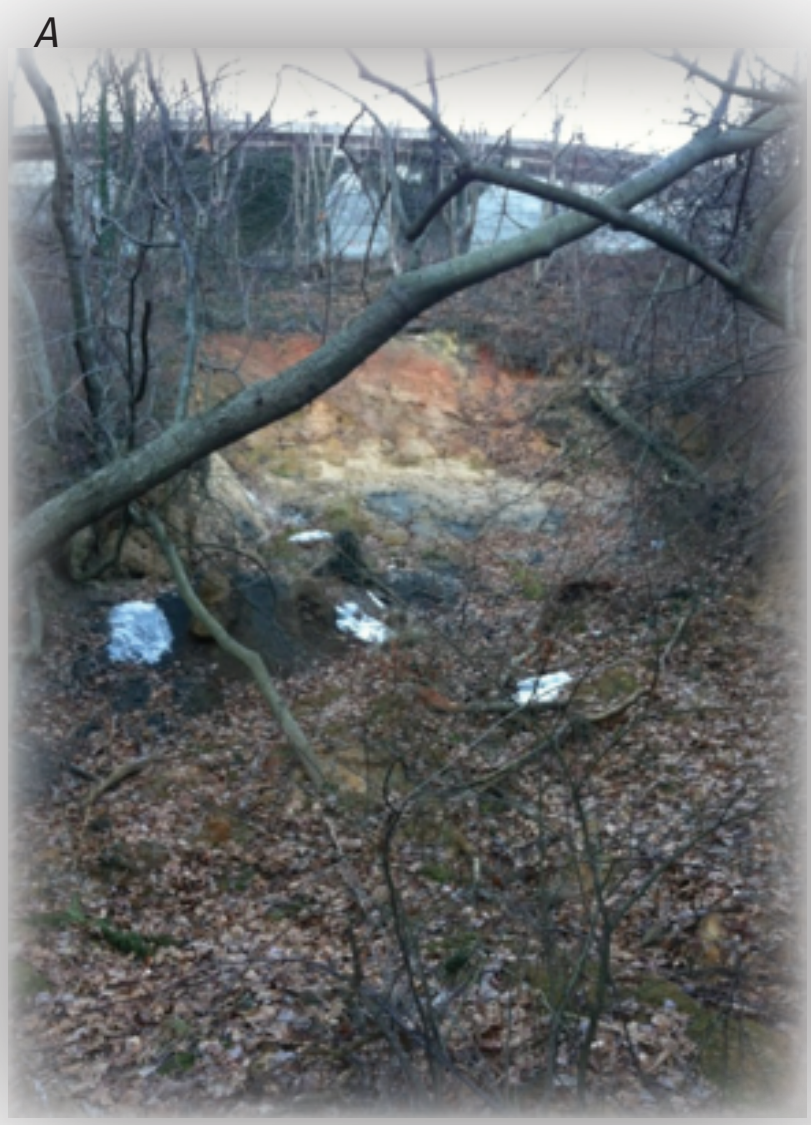

$B$
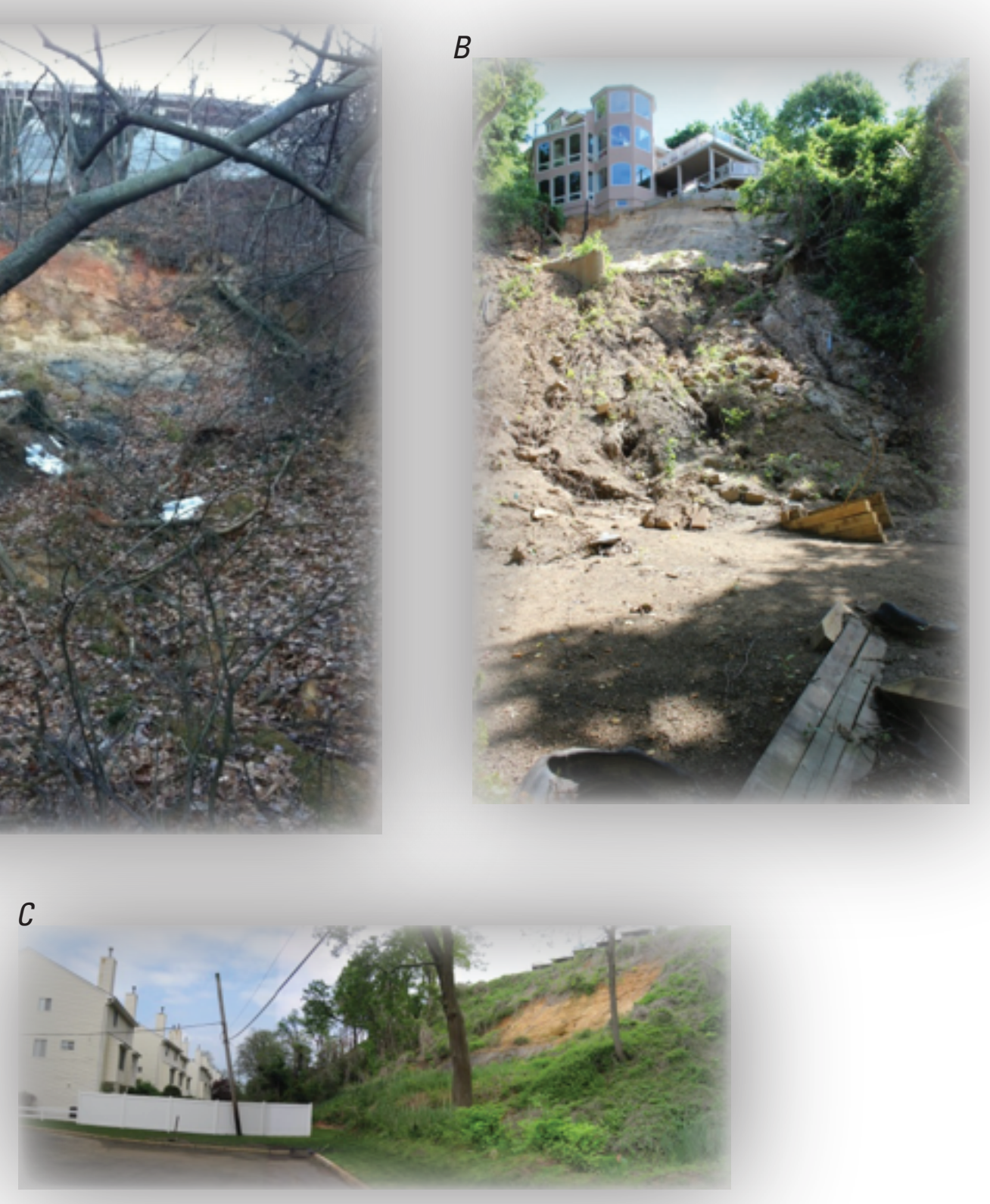

Figure 2. Photographs of three recent shallow landslides in the Atlantic Highlands area, New Jersey: $A$, May 2012 landslide and location of Ocean Boulevard Bridge monitoring site, $B$, April 2014 landslide, and $C$, one of three landslides in the Borough of Highlands that occurred during Tropical Storm Irene in August 2011. (Photos: $A$, by Pam Reilly, USGS; $B$ and $C$, by Francis Ashland, USGS)

sustained and intense rainfall associated with spring nor'easters and late summer-fall tropical cyclones. However, the critical relation between rainfall, soil-moisture conditions, and landslide movement has not been fully defined. The U.S. Geological Survey (USGS) is currently monitoring hillslopes within the Atlantic Highlands area to better understand the hydrologic and meteorological conditions associated with shallow landslide initiation.

\section{Current Landslide Monitoring Sites}

USGS landslide monitoring efforts within the Atlantic Highlands area currently focus on the collection of rainfall, soilmoisture, pore-water-pressure, and slope-movement data that could potentially identify conditions that destabilize a hillslope. Monitoring sites are on predominantly forested slopes where historical landslide movement has occurred (fig. 1). At the Mount Mitchell Scenic Overlook (MMSO) site, two rain gages collect data on rainfall in the forested and open areas (fig. 3). Pore-water pressure is measured at selected locations on the bluff in shallow observation wells by vibrating wire transducers positioned near the bottom of each well. Soil-moisture probes measure the changes in the water content of shallow soils at various depths selected on the basis of the soil profile. At the Ocean Boulevard Bridge (OBB) site, the amount of downslope movement of a recent landslide is recorded by a cable extension transducer that measures the change in distance between two points. Data are collected continuously and recorded every $15-60$ minutes on 


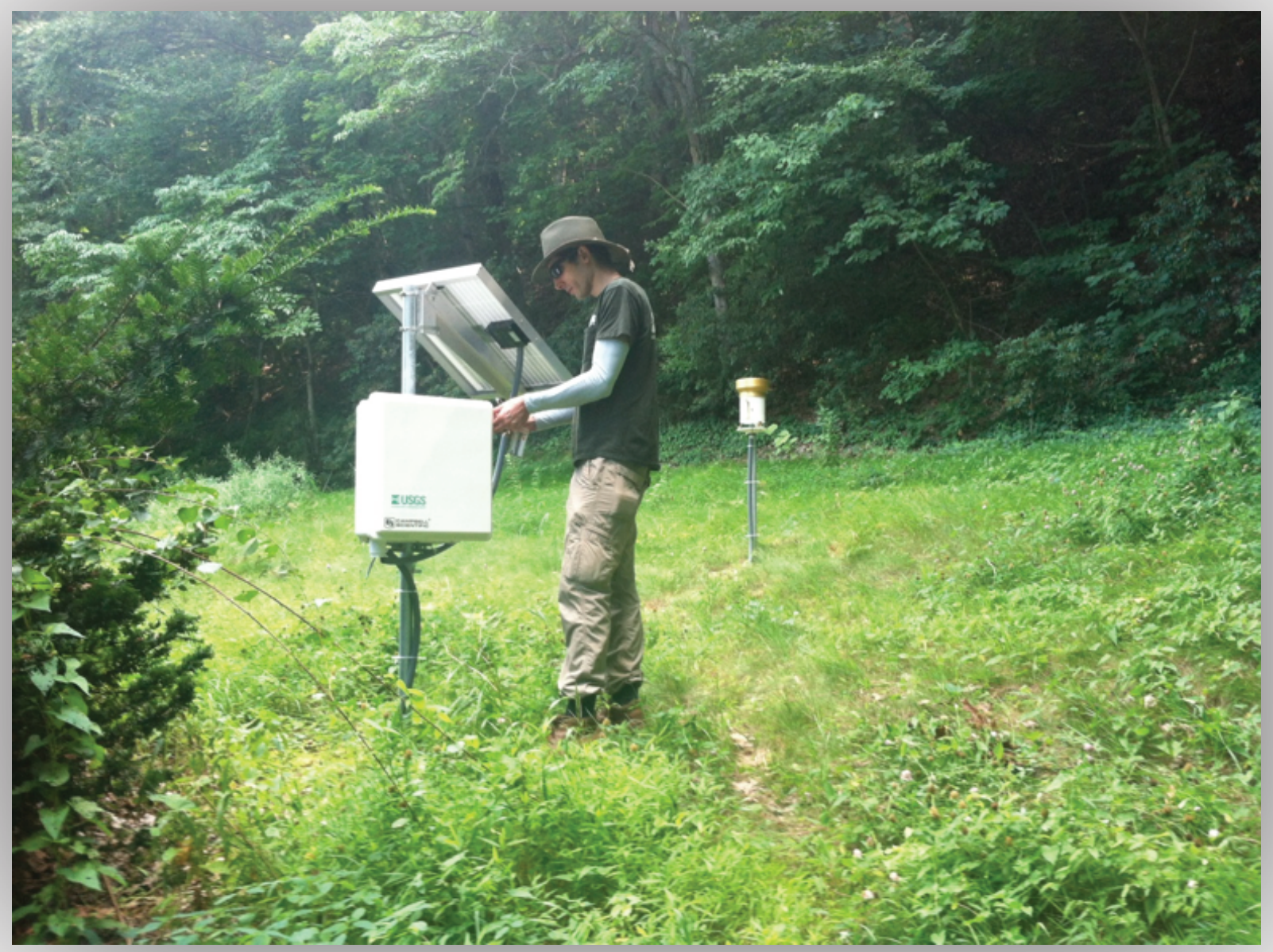

Figure 3. Photograph of a U.S. Geological Survey hydrologist downloading data near the open area rain gage at Mount Mitchell Scenic Overlook, New Jersey. (Photo by Pam Reilly, USGS)

a datalogger. Site visits are routinely made to download data, perform maintenance, and conduct visual inspections.

Scientists at the USGS will use the monitoring results to define the rainfall and hydrologic conditions that trigger landslides by

- evaluating changes in soil moisture and pore-water pressure caused by storms of varying duration, intensity, cumulative rainfall amounts, and seasonality;

- identifying how seasonal variations in soil moisture and porewater pressure affect slope stability; and

- quantifying the critical rainfall conditions that correspond with shallow landslide occurrence.

\section{Potential for a Landslide Early Warning System}

The primary objective of this study conducted by the USGS National Landslide Hazards Program and the USGS New Jersey Water Science Center is to help local emergency officials mitigate landslide hazards by improving understanding of the physical processes that control land movement on the coastal bluffs. As part of the initial research, historical data on rainfall and landslide occurrences were analyzed to identify rainfall conditions that induced shallow slope failure. From these results, two provisional rainfall thresholds were derived that provide a preliminary assessment of the probability of shallow landslides occurring in the area (Ashland and others, 2017).

A goal of this study is to incorporate data from the current monitoring of precipitation, soil-moisture conditions, hydrologic response, and slope movement (Fiore and others, 2017) with the provisional rainfall thresholds into a prototype landslide early warning system for the area. Prior to developing such a system, the ongoing monitoring must provide further insight into the rainfall and hydrologic conditions that result in shallow landslide initiation. Therefore, continued long-term monitoring at these sites is essential to verify that land movement occurs when critical soil-moisture and (or) rainfall threshold conditions are exceeded and to ensure the reliability and accuracy of the prototype landslide early warning system. Development of a landslide early warning system would involve modifying the current monitoring sites so that data are transmitted in near real time to local officials during storms to send an alert of changing conditions in the bluffs and the potential for shallow slope failure.

—Pamela A. Reilly, Francis X. Ashland, and Alex R. Fiore 


\section{References}

Ashland, F.X., Fiore, A.R., and Reilly, P.A., 2017, Characterizing meteorological and hydrologic conditions associated with shallow landslide initiation in the coastal bluffs of the Atlantic Highlands, New Jersey, in De Graff, J.V., and Shakur, A., eds. Landslides: Putting Experience, Knowledge and Emerging Technologies into Practice: Proceedings of the 3rd North American Symposium on Landslides, Roanoke, V.A., June 4-8, 2017, Association of Environmental \& Engineering Geologists Special Publication 27, p. 461-472, ISBN: 978-09897253-7-8

Fiore, A.R., Ashland, F.X., and Reilly, P.A., 2017, Groundwater levels, soil moisture, precipitation, and slope movement in the coastal bluffs of the Atlantic Highlands, New Jersey, 2015-16: U.S. Geological Survey data release, https://dx.doi. org/10.5066/F7959FQB.

Minard, J.P., 1974, Slump blocks in the Atlantic Highlands of New Jersey: U.S. Geological Survey Professional Paper 898, 24 p., accessed February 1, 2015, at https://pubs.er.usgs.gov/ publication/pp898.

New Jersey Department of Environmental Protection (NJDEP), 2016, Landslides in New Jersey, Series DGS06-3, accessed June 8, 2017, at http://www.state.nj.us/dep/njgs/geodata/ dgs06-3.htm

\section{For more information contact}

Francis X. Ashland

U.S. Geological Survey Landslide Hazards Program

703-648-6923 fashland@usgs.gov

Pamela A. Reilly

U.S. Geological Survey

New Jersey Water Science Center

609-771-3900 jankowsk@usgs.gov

Or visit

USGS Atlantic Highlands Landslide Project,

at: https://nj.usgs.gov/hazards/landslides/ahlsproblem.html 